\title{
Integrated Medicine a solution to COVID-19 - A Case Report
}

\author{
Sheetal J. Gupta ${ }^{1}$ and Subodh Tiwari ${ }^{2 *}$ \\ S-VYASA Yoga University, Bengaluru, Karnataka, India ${ }^{1}$ \\ Kaivalyadhama, Lonavala, Maharashtra, India²
}

\section{KEY WORDS}

Yoga

Integrated Medicine

COVID-19

${ }^{*}$ Corresponding Author:

Subodh Tiwari

Kaivalyadhama, Lonavala,

Maharashtra, India

Contact no: 9821160402

E-mail: subodh@kdham.com

\begin{abstract}
More than 213 countries are affected by the global pandemic of COVID-19, which has caused death of more than 500 thousand people around the world. Even after taking all the precaution, one can still get infected with COVID-19. The whole world is working to find a vaccination, where as in alternative system of medicine is focusing on Immunity Boosting helping COVID-19 affected people. The case report shows how Yoga and Ayurveda have helped a COVID-19 positive 84 year's old man to recover.
\end{abstract}

doi: 10.38205/imcr.020125

\section{Introduction}

The global outbreak of coronavirus disease 2019 (COVID-19) in more than 213 countries including China, with more than 11 million people affected, has caused death of more than 500 thousand people (1). Europe has become the new epicenter of COVID-19. USA, Spain, Italy, UK and France are the most affected countries with COVID-19 (2). Density, Tourism and poverty are some of the major reasons for the wide spread of COVID-19.

It is an infectious disease whose carrier may be diagnosed as COVID Positive or may remain asymptomatic. Older people, and those with pre-existing medical condition like cardiovascular disease, diabetes, chronic respiratory disease, or cancer are at higher risk of COVID-19. The best way to prevent and slow down transmission of COVID-19 is stay well informed about the virus and how it spreads. It spreads when a sick person coughs or sneezes. They can spray droplets as far as 6 feet away and if one breathes them in or swallows them, the virus can get into the other person's body. Some people who have the virus don't have symptoms (asymptomatic), but they can still spread the virus as they are the carriers of the virus. One can also residing of the virus by touching a surface or object the virus is be infected with, followed by touching one's mouth, nose, or possibly eyes. Therefore, maintaining social distancing is very important (3-5).

Health Care individuals like doctors, nurses and civil servants like police personnel take all the required precaution such as masks, sanitization, gloves, PPE kits, yet in several cases they have been found to be infected with COVID-19. Therefore, we may note that these precautions are not exhaustive measures to defend oneself from COVID-19 (6).
Where as on one hand, the world is busy in finding an answer to COVID-19 in the form of vaccines, on the other hand alternative healing systems are being used to strengthen the immunity. A lot of claims have been made in last few months, about how the ancient medicine and healing system may help a COVID affected person. However, no scientific proof has been offered to sustain these claims. The present case report, analyzes the effect of Yoga and Ayurveda for COVID-19 in a case presenting with COVID-19.

\section{Case presentation}

An 83-Year-old man was admitted to the Royal Free Hospital, London, on March 17, 2020 for the evaluation of COVID-19. The patient had a healthy lifestyle which included activities such as regular walks, regular indulgence sports/games. His dietary habits were also healthy. However, upon being tested, the patient was diagnosed as COVID 19 positive.

He was a non-smoker though he did consume alcohol occasionally. He showed symptoms of COVID-19 including weakness, unable to sit and breathe properly, unable to digest food and the presence of fluid in his lungs. Though he could speak, he was not aware of what he was speaking, and had self-isolated himself. He complained about chest infection since February 25, 2020 and started self-medicating with antibiotic amoxycillin from March 3, 2020. His symptoms began to worsen, and anti-biotics didn't seem to help any further.

On March 17, 2020 he could not walk and was very weak after 7 days of no food. He still complained of chest infection and felt congestion in his lungs. Being unable to breathe properly, coughing into a towel and inability to eat, an ambulance was called. 7 hours later he was taken to the hospital and 
admitted. He was given an oxygen mask and diagnosed with borderline sepsis. SWAB Test for COVID-19 was performed on March 20, 2020 which was positive. Apart from the said diagnosis, he was also found to have other complications of asthma and hypertension. The next afternoon he felt better and ate for the first time in 8 days.

When he was admitted on 17th March' 2020, he was given Anti-biotics. Anti-biotics continued with no improvement, rather he continued to experience a lot of discomfort in the form of constipation and stomach pain. In hospital on 18th March 2020 enemas were given along with some laxatives which gave him some temporary relief.

From 19-March-2020, some Ayurveda fluid - ginger, turmeric, lemon, honey combination along with Yogic cleansing technique - Neti (nasal cleaning technique) was introduced. He gargled many times that day. On 20th March 2020, some Asana (gentle exercises) along with Pranayam (Breathing techniques) was introduced. He did these practices in an ad-hoc fashion.

\begin{tabular}{|l|l|}
\hline Asana & Duration \\
\hline Neck Rotation & 3-4 Times a Day \\
\hline Hand Rotation & 3-4 Times a Day \\
\hline Shrink and Release Shoulder & 3-4 Times a Day \\
\hline $\begin{array}{l}\text { Standing } \\
\text { - Hip rotation } \\
\text { Shoulder Movements both forward and } \\
\text { - Leg movements shaking both legs }\end{array}$ & $3-4$ Times a Day \\
\hline $\begin{array}{l}\text { Sitting on Bed Side } \\
\text { Vigorously Shake Arms }\end{array}$ & $3-4$ Times a Day \\
\hline Breathing Exercises/Pranayama & 3-4 Times a Day \\
\hline Hand Breath in and out movements & $3-4$ Times a Day \\
\hline $\begin{array}{l}\text { Breath in from Nose and Breath out from } \\
\text { Mouth - (MukhDhauti) }\end{array}$ & 3-4 Times a Day \\
\hline $\begin{array}{l}\text { Alternative nostril breathing (AnulomVilom } \\
\text { Pranayama) 10 Times }\end{array}$ & 3-4 Times a Day \\
\hline Special Breathing (Shitkari Pranayama) & Every 20 minutes \\
\hline Health Care & Whole day along \\
\hline Take water sip to keep the mouth moist \\
\hline $\begin{array}{l}\text { Coconut oil - A teaspoon around the mouth } \\
\text { regularly (to kill bacteria) }\end{array}$ \\
\hline $\begin{array}{l}\text { Warm water with salt gaggle - to disinfect } \\
\text { mouth and throat }\end{array}$ & $\begin{array}{l}\text { Drink warm beverages as much as possible } \\
\text { only way to fight the virus) }\end{array}$ \\
\hline Add ginger and turmeric to all your food/drink & Twice \\
\hline
\end{tabular}

On day 4, i.e. 20th March 2020 the hospital took him off antibiotics as they were not working and were giving him severe constipation and stomach ache. He was on an oxygen mask all the time, taken off here while eating no other medicine for covid - just the oxygen and body's natural resources for healing after practicing the ayurvedic and yogic practices. Gradually, he got stronger, went from a mask to a nasal catheter for oxygen supply, and when for 24 hours the condition was stable without the oxygen support, he was discharged on 25th March' 2020. After coming home cardamom and honey was also introduced, which helped improve further, after which he is much stronger now.

\section{Discussion}

This study effectively proves that yogic practices along with ayurvedic herbs and techniques bring a notable change and improvement in the Covid-19 patient in short duration. Acute pain and constipation of the patient was also healed with the body-mind interventions.

More studies on covid-19 patients should be carried out with standardized protocols to examine the long term effect of integrated medicine on covid-19.

\section{Conclusion}

In earlier studies it has been identified that yoga breathing helps in improving lung function and boosts immunity $(7,8)$. The issue of dealing with cytokines during the infection has been substantive and role of Yoga in this needs to be highlighted (9). Herbs like ginger, turmeric, glycyrrhiza glabra and tinospora cordifolia also helps in improving the immunity which has been proven in the earlier research studies (10). The present case report also concludes that yoga and ayurvedic herbs helps in improving lung capacity and immunity of 83-year-old man and therefore we can say it can be a helpful tool in treatment of COVID positive patients and yoga based treatment should be tried on other COVID positive patients.

\section{Acknowledgment}

Maxine Levy, Maxine Yoga, UK.

\section{Authorship contribution}

SJG: Manuscript preparation, Manuscript editing, reviewing and approval

ST: Delivery of the Yoga Protocol, Data Collection

\section{Informed consent}

Yes, the written informed consent has been obtained from the patient.

\section{Source of funding}

None declared.

\section{Conflict of interest}

The Authors declare no conflict of interest.

Received Date: 15-08-20; Revised Date: 05-01-21

Accepted Date: 08-01-21 


\section{References}

1. World Health Organization; WHO Coronavirus Disease (COVID-19) Dashboard; World Health Organization; 2020; https://www.worldometers.info/

2. United Nations; Department of Economic and Social Affairs; United nation; 2020; https://unstats.un.org/unsd/methodology/m49/

3. Ministry of Health \& Family Welfare, Government of India; Prevention and Management of COVID-19; 2020; https://www.mohfw.gov.in/pdf/ PreventionandManagementofCOVID19FLWEnglish.pdf

4. Ministry of Health \& Family Welfare, Government of India; Detail Question and Answers on COVID-19 for Public; National Health Mission; 2020; https://www.mohfw.gov.in/pdf/FAQ.pdf\#: :text=People $\% 20$ can $\% 20$ catch\%20COVID\%2D,surfaces\%20around\%20the\%20person

5. Center for Disease control and prevention; Covid-19; U.S. Department of Health \& Human Services; 2020; https://www.cdc.gov/coronavirus/2019-ncov/prevent-getting-sick/social-distancing.html
6. Medscape; Almost 600 US Healthcare Workers Have Died from COVID-19; medscape; pg. 1; 2020; https://www.medscape.com/viewarticle/ 932028

7. Hakked CS, Balakrishnan R, Krishnamurthy MN. Yogic breathing practices improve lung functions of competitive young swimmers. Journal of Ayurveda and integrative medicine. 2017 Apr 1;8(2):99-104.

8. Juanamasta IG, Priastana IK. Yoga affect to system immune: A systematic review. InProceeding ICON 3, International Conference on Nursing 2017 (pp. 206-217).

9. Rajbhoj PH, Shete SU, Verma A, Bhogal RS. Effect of yoga module on pro-inflammatory and anti-inflammatory cytokines in industrial workers of lonavala: a randomized controlled trial. Journal of clinical and diagnostic research: JCDR. 2015 Feb;9(2):CC01.

10. Sathiyamoorthy P. Ayurveda for improving Immune system; Herbal medicine research; 2020 May;5'3. 